\title{
ANALISIS STRATEGI PEMASARAN JASA PO. PUSPA JAYA GROUP (Studi Bus AKAP (Antar Kota Antar Provinsi) di Bandar Lampung)
}

\author{
Appin Purisky Redaputri ${ }^{1}$, Kadek Riski $^{2}$ \\ ${ }^{1}$ Fakultas Ekonomi dan Bisnis, Universitas Bandar Lampung \\ J1. Zainal Abidin Pagar Alam No.26, Labuhan Ratu, Kedaton, 35142, Bandar Lampung, \\ Indonesia \\ email: \\ appin@ubl.ac.id \\ adekrisky2017@gmail.com
}

\begin{abstract}
ABSTRAK
PO. Puspa Jaya Group adalah sebuah wadah yang ditempati oleh penyelenggara angkutan wisatawan yang merupakan salah satu bagian dari kemajuan bidang transportasi. Tujuan eksplorasi adalah untuk membedakan dan memperjelas profil teknik administrasi showcasing di PO. Puspa Jaya Group di Bandar Lampung dan membedah teknik periklanan administrasi PO. Puspa Jaya Group di Bandar Lampung. Konfigurasi eksplorasi ini adalah konfigurasi pengujian yang jelas untuk mewakili penyelidikan teknik promosi PO. Puspa Jaya Group. Dilihat dari eksplorasi, terlihat bahwa kuadran I merupakan keadaan yang sepenuhnya menguntungkan, karena memiliki bukaan dan kualitas sehingga dapat memanfaatkan kebebasan yang ada semaksimal mungkin. Metodologi yang harus diterapkan pada kondisi ini adalah membantu pendekatan pembangunan, dimana asosiasi meningkatkan kualitasnya dengan memanfaatkan lucky break yang ada. Organisasi transportasi (PO. Puspa Jaya) membutuhkan dan penting untuk merencanakan metodologi selama rentang bisnisnya, baik untuk pengembangan, menghadapi persaingan, memanfaatkan peluang, dan memperbaiki kondisi yang ada.
\end{abstract}

\section{Kata Kunci: Analisis, Strategi, Pemasaran Jasa.}

\section{PENDAHULUAN}

Persaingan pasar semakin beragam dan sangat serius, sehingga kemajuan lain penting yang dapat mendorong pembeli premium dalam memilih dan tertarik pada item atau layanan yang ditawarkan, ini mengharapkan organisasi untuk melakukan latihan mereka seefektif dan seefektif mungkin, sehingga organisasi dapat dipastikan dalam jangka waktu tertentu. umumnya panjang. Banyak organisasi menyelesaikan pemikiran dan kemajuan inventif dalam mengalahkan persaingan yang ada, terutama pada organisasi yang bekerja dengan bidang serupa.

Perkembangan bisnis transportasi elah didorong oleh perkembangan dan kemajuan berbagai jenis organisasi yang menggabungkan transportasi secara berbeda dan transportasi ini dikenal sebagai organisasi administrasi transportasi. Salah satu jenis angkutan umum adalah angkutan darat antar masyarakat perkotaan, seperti Angkutan, Kereta Api, Trevel dan angkutan darat lainnya. Dalam bisnis transportasi, persaingan yang saat ini sedang berkembang atau tinggi telah menyebabkan semakin banyaknya organisasi yang berlomba-lomba melihat area bisnis ini sebagai bisnis yang menawarkan keuntungan dengan kemungkinan yang menjanjikan. Dengan pengaturan persaingan yang sangat serius, setiap organisasi diperlukan untuk menjalankan metodologi yang benar untuk menarik klien sebanyak mungkin, tanpa prosedur tunggal akan menyebabkan organisasi gagal dan menurunkan pendapatan. 
Menawarkan dukungan yang menyenangkan dan tak tertandingi adalah teknik penting karena dapat mendasarkan lebih banyak klien baru. Administrasi adalah salah satu segmen penting dari nilai signifikan yang mengatur kemajuan organisasi mana pun. Organisasi administrasi transportasi yang perlu menciptakan dan memperoleh keunggulan harus memiliki pilihan untuk menawarkan jenis bantuan berkualitas dengan biaya rendah dan dukungan klien yang hebat dari pesaing yang berbeda. Untuk memenuhi loyalitas konsumen dalam bisnis bantuan, kualitas administrasi sangat penting untuk diawasi dengan baik oleh organisasi.

Kualitas administrasi sangat penting dalam bisnis bantuan. Kualitas bantuan yang luar biasa adalah cara yang bermanfaat untuk mengembangkan lebih banyak klien baru, mempertahankan klien yang sudah ada, menjauhkan diri dari penerbangan klien, dan membuat titik fokus luar biasa yang tidak hanya serius mengenai biaya, dengan membuat atribut mereka sendiri. Jika bantuan dirasakan benar untuk dibentuk.

Sebagai organisasi yang bekerja dengan bisnis bantuan, untuk memberikan lebih banyak insentif bagi klien atau pelanggan, sangat penting untuk fokus pada sifat administrasi yang diberikan kepada klien atau pelanggan, misalnya, kualitas administrasi. Menurut semua yang sulit dipahami, misalnya perangkat keras, inovasi, kerapian dan kenyamanan ruangan, kualitas administrasi diidentifikasikan dengan kapasitas pekerja untuk diberikan administrasi secara lugas dan untuk memenuhi klien sejauh kecepatan dalam bantuan, keinginan yang representatif untuk membantu klien., dan masukan perwakilan, administrasi yang diidentifikasi dengan informasi perwakilan tentang kesenangan dan kapasitas mereka untuk mendukung dan diberi keyakinan bahwa semuanya baik dan tepercaya, administrasi terkait pertimbangan kualitas, korespondensi yang baik, dan pemahaman kebutuhan klien seperti bantuan yang wajar dan koneksi klien. Saat ini, pelanggan memiliki banyak pertimbangan untuk menggunakan layanan seperti kantor dan administrasi di armada. Jika presentasi tergantung tidak sesuai dengan asumsi, bisa jadi klien bermasalah sehingga tidak ada pembelian berulang-ulang yang dilakukan atau memberi petunjuk kepada klien lain bahwa hal-hal buruk pada armada akan sangat mempengaruhi armada.

PO. Puspa Jaya Bandar Lampung merupakan organisasi yang ditempati oleh penyelenggara angkutan wisatawan yang merupakan salah satu bagian dari kemajuan kawasan transportasi. Kawasan transportasi ini berkembang pesat, hal ini terlihat dari semakin berkembangnya variasi yang menjamin bisnis ini. Organisasi PO. Puspa Jaya Group berlokasi di Jl. Soekarno - Hatta Nomor 3, Hajimena, Lokal Natar, Pemerintahan Lampung Selatan, Lampung. Klien organisasi PO. Puspa Jaya Bandar Lampung umumnya adalah orang asing yang akan kembali ke daerahnya atau bepergian ke suatu tempat. Ada banyak organisasi yang menempati bidang komparatif di Bandar Lampung yang menjadi pesaing PO. Puspa Jaya Bandar Lampung, tentu saja, para pesaing ini memiliki metodologi bisnis mereka sendiri yang tidak diragukan lagi memiliki bahaya yang signifikan. Untuk PO. Puspa Jaya Group memiliki prosedur periklanan yang menggarisbawahi loyalitas dan kenyamanan konsumen. Pesan PO. Temu Puspa Jaya juga dapat meningkatkan pendapatan administrasi sehingga manfaat berbasis lebih ideal, maka perlu dikaji prosedur promosi bantuan di PO. Puspa Jaya Group, artinya menentukan kelayakan teknik showcase administrasi terhadap pendapatan administrasi PO. Gathering Puspa Jaya. 
Tabel 1. Pendapatan Bus Antar Kota Antar Provinsi (AKAP) PO. Puspa Jaya Group Tahun 2018-2020

\begin{tabular}{ccc}
\hline No & Tahun & Pendapatan \\
\hline 1 & 2018 & Rp. 5.796.442.766 \\
2 & 2019 & Rp. 4.161.195.500 \\
3 & 2020 & Rp. 3.875.332.417 \\
\hline
\end{tabular}

Sumber: PO. Puspa Jaya Group

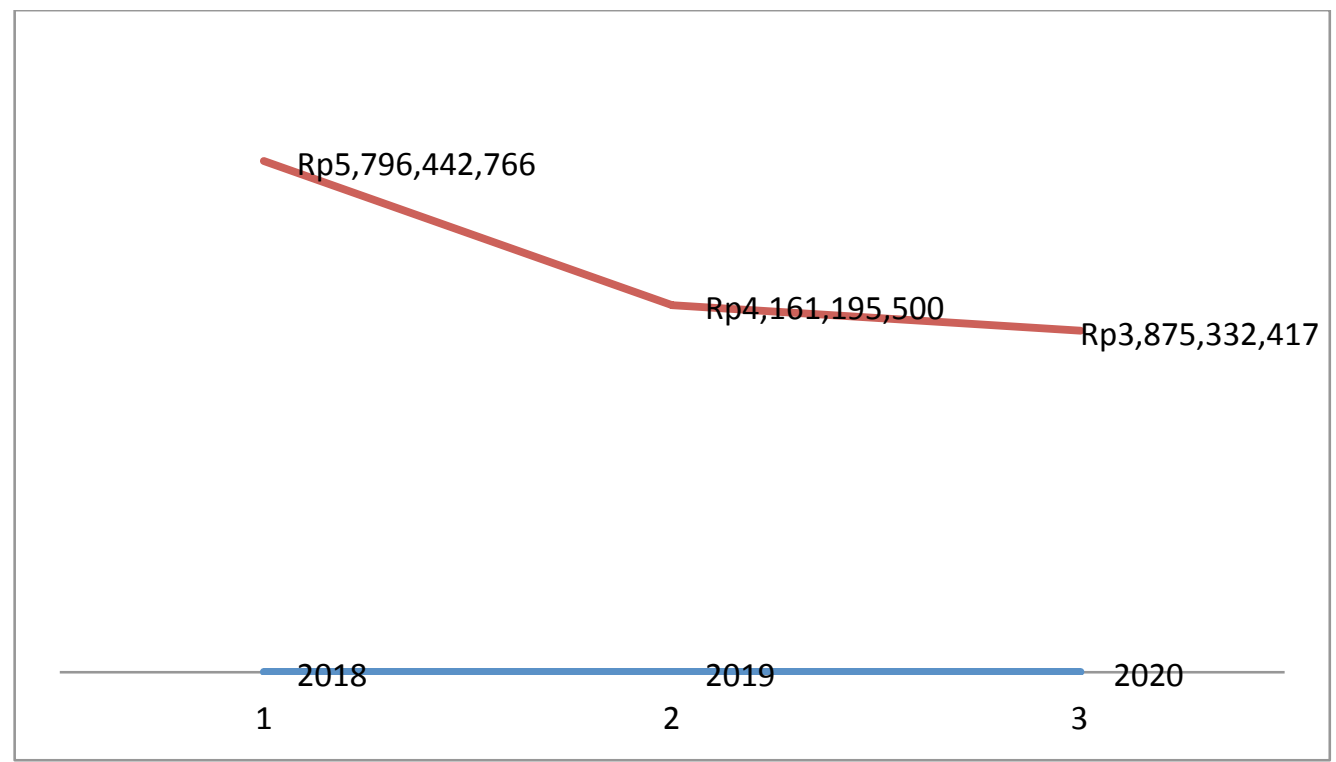

Gambar 1. Grafik Perkembangan Pendapatan Bus AKAP PO. Puspa Jaya Group Sumber Data : PO. Puspa Jaya

Dari diagram 1. layout minat pembeli dalam memanfaatkan administrasi PO. Temu Puspa Jaya dari tahun ke tahun semakin berkurang. Pada 2018 hingga 2020, penur. PO. Puspa Jaya Group mengalami mengalami penurunan, salah satunya adanya pandemi Covid 19.. Oleh karena itu sangat penting untuk memiliki sesuatu atau teknik untuk PO. Temu Puspa Jaya dapat menambah pemasukan administrasi sehingga ketergantungan kemanfaatan lebih ideal, sehingga sangat penting untuk membedah pendampingan yang menampilkan metodologi di PO. Puspa Jaya Group, artinya memutuskan kelayakan prosedur bantuan periklanan pada pendapatan administrasi PO. Gathering Puspa Jaya.

Sebagai informasi serupa, selanjutnya adalah informasi tentang pesaing PO. Puspa Jaya Group, tepatnya PO. Karona Gathering yang melayani kursus Antar Kota Antar Provinsi (AKAP)

Tabel 2. Pendapatan Bus Antar Kota Antar Provinsi (AKAP) PO. Karona Group Tahun 2018-2020

\begin{tabular}{ccc}
\hline No & Tahun & Pendapatan \\
\hline 1 & 2018 & Rp. 6.127.452.500 \\
2 & 2019 & Rp. 5.025.115.450 \\
3 & 2020 & Rp. 4.016.335.300 \\
\hline
\end{tabular}

Sumber: PO. Karona Group

Dari Tabel 1.2 diketahui bahwa Pendapatan Antar Kota Antar Provinsi (AKAP) angkutan PO. Karona Group tahun 2018-2020 terbilang lebih tinggi dari PO. Puspa Jaya Group, alhasil 
PO. Temu Puspa Jaya harus menjalankan sistem periklanan untuk membangun pendapatan dari angkutan Antar Kota Antar Provinsi (AKAP).

\section{TINJAUAN PUSTAKA}

Menurut Mary Parker Follet (2000: 18) "Dewan adalah spesialisasi menangani pekerjaan melalui orang lain." Sesuai Stoner (2006) "Eksekutif adalah siklus persiapan, koordinasi, penggerak, dan pengendalian upaya individu yang berwibawa dan memanfaatkan semua aset hierarkis untuk mencapai tujuan yang telah ditetapkan sebelumnya." Seperti yang diindikasikan oleh G. R. Terry (2002: 18) "Papan adalah suatu gerakan yang terdiri dari persiapan, penyusunan, pengontrolan dan pengamatan yang dilakukan untuk mencapai tujuan yang telah ditetapkan sebelumnya".

Sesuai Daryanto (2013) yang dikutip oleh Hamdani, H., Badaruddin, B., dan Mariah, M. (2020). Mempromosikan eksekutif adalah penyelidikan, pengaturan, penggunaan, dan kontrol proyek yang dimaksudkan untuk membuat, membuat, dan menjaga perdagangan yang produktif dengan pembeli target untuk mencapai tujuan hierarki. Periklanan dewan mencakup permintaan persiapan para eksekutif, yang pada akhirnya mencakup hubungan klien dengan dewan. Jadi, mempromosikan dewan adalah permintaan para eksekutif. Seperti yang ditunjukkan oleh (Kotler dan Keller, 2006) yang dikutip oleh Wardana, P. A. (2020, April), mempromosikan dewan adalah keahlian dan studi dalam memilih sektor bisnis yang obyektif melalui kreasi, penyesuaian dan korespondensi klien.

Sesuai dengan Private dan Irawan (2008), prosedur sangat penting untuk organisasi dimana metodologi adalah salah satu pendekatan untuk mencapai tujuan organisasi. Menurut Swastha, sistem adalah perkembangan usaha luar biasa yang menguraikan bagaimana organisasi harus bertindak untuk mencapai tujuannya. Metodologi adalah keseluruhan gagasan tentang bagaimana organisasi dikoordinasikan dan semua latihan sehingga bisnis berjalan secara efektif, bersaing dan bergantung pada manfaat bagi investor. Dari kesepakatan di atas, maka sistem cenderung dianggap sebagai gagasan atau metode total untuk mencapai tujuan yang ingin dicapai.

\section{METODOLOGI}

Model pemeriksaan ini adalah model eksplorasi yang berbeda untuk menggambarkan penyelidikan administrasi PO yang menampilkan prosedur. Grupi Puspa Jaya. Pemeriksaan SWOT merupakan pemeriksaan yang terdiri dari miniatur penyelidikan alam yang bertujuan untuk mengenali kualitas dan kekurangan organisasi, dan pemeriksaan ekologi skala penuh yang bertujuan untuk menentukan peluang dan bahaya bagi organisasi. Kisi BCG digunakan untuk menentukan posisi PO. Puspa Jaya Bandar Lampung Gathering from development and piece of pie. Jika posisi tersebut diketahui, itu akan mengungkap teknik promosi apa yang dapat dilakukan organisasi.

\section{HASIL DAN PEMBAHASAN}

a. Analisis SWOT (Stenght, Weakness, Opportunity, Threats)

Mengingat pengisian struktur investigasi PO SWOT. Puspa Jaya Bandar Lampung memperoleh keadaan faktor dalam organisasi (kualitas dan kekurangan) dan keadaan variabel luar organisasi (bukaan dan bahaya), sebagai berikut: 
Tabel 3. Analisis Faktor Strategi Internal

Faktor Strategi Internal

Bobot Rating Skor

Kekuatan :

$\sim$ Aman

$\begin{array}{lll}0,17 & 4 & 0.68\end{array}$

$\sim$ Bus tepat waktu, tidak ada oper penumpang

$0,12 \quad 3 \quad 0,36$

$\sim$ Armada baru dan banyak

$0,17 \quad 4 \quad 0,68$

$\sim$ Pekerja loyal dan berpengalaman

$\begin{array}{lll}0,13 & 3 & 0,39\end{array}$

Kelemahan :

$\begin{array}{lllll}\sim \text { Belum adanya fasilitas teknologi yang mendukung } & 0,12 & 1 & 0,12\end{array}$

$\begin{array}{llll}\sim \text { Tidak ada data base pelanggan dan customer service. } & 0,17 & 2 & 0,34\end{array}$

\begin{tabular}{llll}
$\sim$ Tidak adanya sistem pengontrolan yang efektif & 0,12 & 2 & 0,24 \\
\hline
\end{tabular}

Total $1,00 \sim \sim 2,13$

Tabel 4. Analisis Faktor Strategi Eksternal

Faktor Strategi Eksternal

Bobot Rating Skor

Peluang:

$\sim$ Datangnya pengguna pendatang baru

$0,11 \quad 4 \quad 0,44$

$\sim$ Pariwisata terus meningkat

$0,35 \quad 4 \quad 1,48$

$\sim$ Upaya dilakukan promosi

$0,20 \quad 3 \quad 0,63$

$\sim$ Adanya campur tangan pemerintah

Ancaman :

$\begin{array}{llll}\sim \text { Kebijakan pemerintah (BBM dan biaya penyebrangan) } & 0,14 & 3 & 0,63\end{array}$

$\begin{array}{llll}\sim \text { Munculnya perusahaan otobus (PO) yang sejenis } & 0,21 & 3 & 0,63\end{array}$

$\sim$ Suku cadang bus tinggi

$0,10 \quad 3$

$\begin{array}{lll}\text { Total } & 1,00 & 3,35\end{array}$

Mengingat penyelidikan kisi IFE bergantung pada skor habis-habisan 3,0. Skor umum menunjukkan bahwa kapasitas organisasi dalam memanfaatkan kualitas untuk mengatasi kekurangan lebih baik dari yang diharapkan. Mengingat ujian grid EFE bergantung pada skor 3,37 . Secara umum menunjukkan bahwa organisasi dapat memanfaatkan peluang dan menaklukkan bahaya dengan baik. Mengingat keduanya bergantung pada semua yang diperoleh melalui jaringan IFE dan EFE, maka set pada kerangka kerja IE (Interior Luar) untuk menentukan posisi organisasi saat ini. 


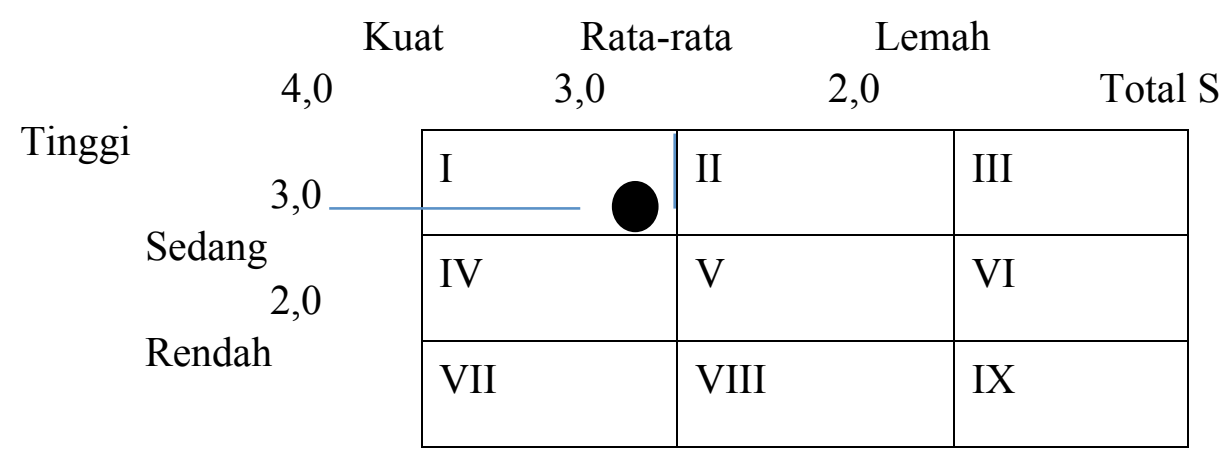

Total Skor Faktor Eksternal

Gambar 2 Matriks IE PO. Puspa Jaya Bandar Lampung

Dari pengujian kerangka IE, sangat baik dapat dilihat bahwa PO. Puspa Jaya Bandar Lampung berada pada kuadran I. Hal ini menunjukkan PO. Puspa Jaya Bandar Lampung saat ini berada dalam situasi yang banyak berkembang (berkembang secara konstan). Dari posisi organisasi, sistem elektif yang sesuai untuk digunakan di kuadran ini adalah prosedur yang ditingkatkan (infiltrasi pasar, kemajuan pasar dan peningkatan item) atau metodologi campuran (dalam campuran terbalik, penggabungan ke depan dan kombinasi level).

Prosedur serius menggabungkan metodologi infiltrasi pasar, peningkatan pasar, dan kemajuan barang. Metodologi masuk pasar adalah pekerjaan untuk membangun sepotong kue dari item atau administrasi yang seperti sekarang di pasar melalui upaya menampilkan yang lebih meningkat. Metodologi masuk pasar harus dimungkinkan dengan memperluas kualitas barang dan memperluas kemajuan kesepakatan. Metodologi kemajuan pasar, tepatnya penyajian barang atau administrasi di wilayah baru. Kemudian, metodologi peningkatan item memperluas kesepakatan dengan memperluas atau mengubah item atau administrasi yang ada. Metodologi kombinasi menggabungkan rekonsiliasi maju, dalam koordinasi terbalik, dan campuran datar. Koordinasi ke depan, khususnya memperluas kontrol grosir atau pengecer. Sebaliknya, bergabung memperluas otoritas atas penyedia. Kemudian, penggabungan datar membangun otoritas atas pesaing. Teknik yang bergantung pada grid IE ketika semua dikatakan selesai hanya menggambarkan posisi PO. Puspa Jaya Bandar Lampung. Oleh karena itu, penggunaan sistem pada jaringan IE dilengkapi dengan kisi-kisi SWOT sebagai langkah yang harus dilakukan oleh PO. Puspa Jaya Bandar Lampung dari pengembangan framework IE.

Daripada grid SWOT (Tabel 3), itu cenderung dikonsolidasikan untuk memutuskan teknik untuk komponen dalam dan luar:

1. Prosedur SO:

a. Dengan kemajuan inovasi data, organisasi diperlukan untuk mengikuti dan fokus pada transportasi sesuai jadwal, tanpa tugas wisatawan untuk menarik pembeli untuk membeli

b. Peningkatan administrasi SDM yang lebih besar,

c. Meningkatkan administrasi penawaran melalui persiapan pertunjukan.

2. Prosedur WO:

a. Biaya barang lebih tinggi daripada pesaing dapat diramalkan dengan kualitas yang dapat diterima,

b. Penurunan harga yang lebih luas,

c. Latihan khusus yang diperluas, misalnya melalui promosi

3. Teknik ST 
a. Peningkatan kualitas dan kehebatan administrasi untuk menghadapi organisasi pesaing yang ada,

b. Meningkatkan sifat SDM yang memiliki pengetahuan tentang bidang kesepakatan melalui persiapan promosi.

4. Prosedur WT:

a. Tingkatkan rabat lebih lanjut untuk membangun kesepakatan

b. Kemajuan yang lebih luar biasa untuk menghadapi persaingan.

c. Sirkulasi yang signifikan mengarahkan pada tekanan bagian dari organisasi.

Mengingat perpaduan teknik SWOT, khususnya metodologi SO, sistem WO, prosedur ST dan teknik WT, maka cenderung terlihat bahwa teknik faktor interior seperti halnya prosedur faktor luar organisasi harus diaktualisasikan oleh organisasi. . Dengan bergabung dalam sistem SWOT, organisasi belum sepenuhnya mewujudkannya. Jadi itu menyiratkan PO. Puspa Jaya Bandar Lampung bukan masalah sistem serius yang masuk akal tergantung pada investigasi SWOT.

\section{Analisis Matrik Pertumbuhan Bagian Pasar (BCG)}

Pemeriksaan jaringan pengembangan bagian dari industri keseluruhan, ada dua tomahawk, khususnya poros vertikal dan hub yang rata. Hub vertikal menggambarkan tingkat perkembangan pasar di mana sektor bisnis yang sedang berkembang mendemonstrasikan pembukaan bisnis, hub level menggambarkan ukuran keseluruhan bagian kue yang mencerminkan dominasi organisasi. PO. Puspa Jaya Bandar Lampung dapat menentukan situasi unit khususnya dengan mencari tingkat perkembangan pasar dan bagian umum dari pangsa industri secara keseluruhan.

Tingkat Pertumbuhan Pasar:

$\mathrm{g}=\mathrm{n}-1 \sqrt{\mathrm{Pn} / \mathrm{P} 1-1 \times 100 \%}$

Keterangan :

Dari data pangsa pasar PO. Puspa Jaya Bandar Lampung dapat diketahui:

Pn $=$ Penjualan tahun terakhir $(2019=2.335 .300 .000)$

P1 = Penjualan tahun pertama $(2017=1.693 .728 .000)$

$\mathrm{n}=$ Periode tahun

$\mathrm{Pn}=2.335 .300 .000$

$\mathrm{P} 1=1.693 .728 .000$

$\mathrm{n}=5$

$\mathrm{g}=\mathrm{n}-1 \sqrt{\mathrm{Pn} / \mathrm{P} 1}-1 \times 100 \%$

$=5-1 \sqrt{2.335 .300 .000 / 1.693 .728 .000}-1 \times 100 \%$

$=4 \sqrt{1,378792817}-1 \times 100 \%$

$=1,08-1 \times 100 \%$

$=0,08 \times 100 \%$

$=8 \%$

PO menangani tingkat perkembangan pasar. Puspa Jaya Bandar Lampung sebesar 8\% menunjukkan tingkat pembangunan yang rendah karena di bawah $10 \%$. Sementara itu, untuk menentukan bagian umum dari keseluruhan industri, perhitungan yang menyertai 
digunakan:

Pangsa Pasar Relatif =

\section{Pangsa pasar perusahaan}

Pangsa pasar pesaing terbesar

$=\frac{29,97}{38,36}$

$=0,8 \%$

Bagian relatif dari pai PO. Puspa Jaya Bandar Lampung sebesar 0,8\% menunjukkan bahwa kesepakatan organisasi 0,8 kali lebih tinggi daripada organisasi pesaing terbesar. Dari besarnya tingkat perkembangan pasar dan ukuran keseluruhan potongan kue, posisi barang dapat diperjelas. PO. Puspa Jaya Bandar Lampung dalam Kerangka BCG.

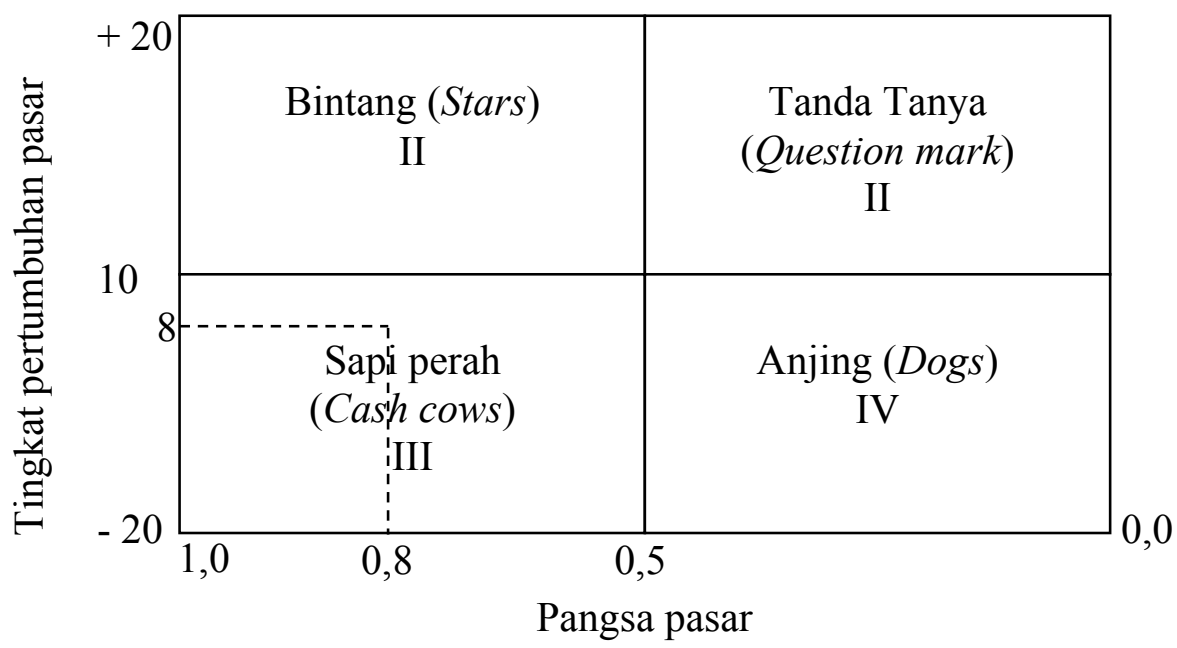

Gambar 4.2

Posisi Produk PO. Puspa Jaya Bandar Lampung dalam Matrik BCG

Dari gambar grid BCG pada situasi item PO. Puspa Jaya Bandar Lampung berada dalam situasi sapi perah, posisi ini menunjukkan bisnis yang secara umum memiliki pangsa industri yang moderat secara keseluruhan dengan tingkat perkembangan yang menurun. Jika unit khusus berada dalam posisi uang dan mulai kehilangan bagian umumnya dari keseluruhan industri, organisasi harus menginvestasikan kembali aset di unit khusus tersebut untuk kembali ke posisi surgawi. Sistem yang harus dibuat oleh PO. Puspa Jaya Bandar Lampung dalam hal cash cows, khususnya: metodologi pengembangan item atau perluasan item. Dari pemeriksaan subjektif kerangka BCG, terlihat bahwa PO. Puspa Jaya Bandar Lampung belum memiliki pilihan untuk mengaktualisasikan teknik yang cukup serius, seperti yang ditunjukkan oleh investigasi kisi BCG.

PO. Puspa Jaya Bandar Lampung dalam sepotong pai bisa dikatakan bisa menjadi peminat pasar. Teknik yang harus dimungkinkan sebagai penganut pasar adalah:

1. Penawaran administrasi ke berbagai porsi pasar seperti populasi keseluruhan atau organisasi yang berbeda untuk menghindari kontak langsung dengan pelopor pasar, untuk situasi ini PO. Puspa Jaya Bandar Lampung menetapkan kesepakatan atau kerjasama 
pemahaman (MM) dengan organisasi, sekolah dan kantor yang berbeda di Wilayah Lampung dalam hal perpindahan perwakilan dan kapal.

2. Organisasi harus memiliki pilihan untuk menetapkan tujuan dan saingan vital, khususnya dengan menyerang organisasi sebesar Karona Rajabasa Utama Transport, melaksanakan strategi nilai yang lebih masuk akal sambil menjaga kesejahteraan dan hiburan.

\section{KESIMPULAN}

Dari pemeriksaan dan perbincangan sangat mungkin dapat beralasan demikian

a. Strategi pemasaran jasa pada PO. Puspa Jaya Group di Bandar Lampung adalah dengan menjual jasa ke pangsa pasar yang berbeda seperti masyarakat umum atau perusahaan lain untuk menghindari berhadapan langsung dengan pemimpin pasar, dalam hal ini PO. Puspa Jaya Bandar Lampung membuat kesepakatan atau perjanjian kerja sama (MoU) dengan dinas-dinas, sekolah dan instansi lain yang ada di Provinsi Lampung mengenai perjalanan wisata (tour) dan antar jemput karyawan

b. Analisis strategi pemasaran jasa PO. Puspa Jaya Group di Bandar Lampung, dimana berdasarkan hasil penelitian diketahui strategi pemasaran jasa PO. Puspa Jaya Group di Bandar Lampung berada pada kuadran I dimana situasi yang sangat menguntungkan, karena memiliki peluang dan kekuatan sehingga dapat memanfaatkan peluang yang ada. Strategi yang harus diterapkan dalam kondisi ini adalah mendukung kebijakan pertumbuhan, yaitu organisasi mengoptimalkan kekuatan untuk menangkap peluang yang ada. Oleh karena itu PO Puspa Jaya melakukan hal hal sebagai berikut :

1) Perusahaan Otobus (PO. Puspa Jaya) butuh dan perlu melakukan perancangan strategi dalam penjalanan bisnisnya, baik untuk bertumbuh, menghadapi persaingan, menangkap peluang, maupun memperbaiki kondisi yang ada.

2) Perancangan strategi yang tepat untuk PO. Puspa Jaya dalam upaya penerapan strategi bisnis dengan memanfaatkan peluang dan kekuatan dalam melakukan persaingan di industri transportasi bus, yaitu dengan meleburkan analisa lingkungan sebelumnya dalam matrix SWOT. Hasilnya adalah perusahaan memenuhi kondisi untuk melakukan strategi diversifikasi terkait, pembukaan jalur baru untuk pariwisata, melakukan perbaikan pada kondisi sekarang yang dibantu dengan implementasi peremajaan armada.

\section{DAFTAR PUSTAKA}

Daryanto, (2011), Showcasing The executive, PT Sarana Instructional exercise Nurani, Bandung.

Dunan, H., Antoni, M. R., Redaputri, A. P., dan Jayasinga, H. I. (2020). Pemeriksaan Komponen yang Mempengaruhi Transaksi Kaos "Waleu" Lampung di Bandar Lampung. JBMI (Diary of Business, Dewan dan Informatika), 17 (2), 167-185.

Fernico Gunawan Lubis (2016), Pemeriksaan Posisi Bisnis Penting PT Lautan Teduh Interniaga di Bandar Lampung. Buku Harian Pimpinan Cabang, Tenaga Kerja Keuangan dan Bisnis, Perguruan Tinggi Lampung

Hamdani, H., Badaruddin, B., dan Mariah, M. (2020). Ujian Sistem Pertunjukan Bisnis Vastness Bistro di Rezim Pinrang. Akmen Logical Diary, 17 (1), 53-65.

Kotler dan Keller, (2009), Promoting The executive Release 13 volume 2, Distributer Erlangga, Jakarta

Laili, N. L. (2019). Mempromosikan Pemeriksaan Metodologi dalam Upaya Memperluas Deals di PT. Banjarmasin Express. Logical Diary of Business Financial aspek, 5 (3).

Laksana, F. (2018) Promosi Eksekutif, Distributer Graha Ilmu, Yogyakarta. 
Lupiyoadi, R dan Hamdani, A. (2016) Administrasi Promosi Para Eksekutif Versi 2, Salemba Empat, Jakarta.

Lupiyoadi, R. (2013) Bantuan Promosi Pengurus Berbasis Kompetensi, Edisi 1 Distributer Salemba Empat, Jakarta.

M. Yusuf S Barusman, Appin Purisky Redaputri, Investigasi Metodologi Bisnis Marley's Bistro Espresso and Resto Bandar Lampung, OSF Preprints.

Rangkuti, Freddy. (2006). Investigasi SWOT: Metode untuk Membongkar Kasus Bisnis. Jakarta: Gramedia Pustaka Utama.

Sugiat, J. (2019). Penggunaan Sistem Perpaduan Promosi Administrasi dan Teknik Periklanan Sosial untuk Pengembangan Nilai Administrasi dan Sarannya untuk Kepercayaan Pemahaman di Perguruan Tinggi Swasta di Priangan Timur. Sudut pandang: Diary of Regulatory Sciences, 1 (2), 174-195.

Sugiyono. (2010). Teknik Eksplorasi Kuantitatif, Subyektif, dan R dan D. Bandung: Distributor Alfabeta

Swastha, Basu dan Irawan (2016), Saat Ini Mempromosikan Dewan. Kebebasan. Yogjakarta. Tjiptono, F dan Chandra, G. (2016), Administrasi Periklanan (Standar, Aplikasi, dan Eksplorasi), Andi, Yogyakarta.

Tjiptono, F. (2016), Key Showcasing, Reconsidered Release, CV. Andi Balance, Yogyakarta. Wardana, P. A. (2020, April). Pemeriksaan Prosedur Menampilkan Transaksi yang Diperluas Memanfaatkan Investigasi Swot Di CV. RJM. Dalam Prosedur Kelas Umum Staf Perancangan, Perguruan Tinggi Maarif Hasyim Latif Sidoarjo (Vol. 1). 